\title{
Reclassification of Trichlorobacter thiogenes as Geobacter thiogenes comb. nov.
}

Correspondence

Kelly P. Nevin

knevin@microbio.umass.edu

\author{
Kelly P. Nevin, Dawn E. Holmes, Trevor L. Woodard, Sean F. Covalla \\ and Derek R. Lovley
}

Department of Microbiology, University of Massachusetts, Amherst, MA 01003, USA

\begin{abstract}
Reclassification of the species Trichlorobacter thiogenes as Geobacter thiogenes comb. nov. is proposed on the basis of physiological traits and phylogenetic position. Characteristics additional to those provided in the original description revealed that the type strain (strain $\mathrm{K}_{1}{ }^{\mathrm{T}}=\mathrm{ATCC}$ BAA $-34^{\top}=\mathrm{JCM} 14045^{\top}$ ) has the ability to use $\mathrm{Fe}(\mathrm{III})$ as an electron acceptor for acetate oxidation and has an electron donor and acceptor profile typical of a Geobacter species, contains abundant c-type cytochromes, and has a temperature optimum of $30^{\circ} \mathrm{C}$ and a pH optimum near $\mathrm{pH} 7.0$; traits typical of members of the genus Geobacter. Phylogenetic analysis of nifD, recA, gyr $B, r p o B$, fus $A$ and $16 \mathrm{~S}$ rRNA genes further indicated that $T$. thiogenes falls within the Geobacter cluster of the family Geobacteraceae. Based on extensive phylogenetic evidence and the fact that $T$. thiogenes has the hallmark physiological characteristics of a Geobacter species, Trichlorobacter thiogenes should be reclassified as a member of the genus Geobacter.
\end{abstract}

Trichlorobacter thiogenes strain $\mathrm{K}^{\mathrm{T}}$ (=ATCC BAA$\left.34^{\mathrm{T}}=\mathrm{JCM} 14045^{\mathrm{T}}\right)($ De Wever et al., 2000) was affiliated with the genus Trichlorobacter mainly on the basis of its ability to dechlorinate trichloroacetic acid. However, this Gram-negative, non-motile, short curved rod has the ability to use acetate as an electron donor, similar to all Geobacter species in the family Geobacteraceae (Lovley et al., 2004). T. thiogenes also shares other important physiological traits with many Geobacter species, such as $S^{0}$ and fumarate reduction (Lovley et al., 2004). Immediately after the publication of the original description of $T$. thiogenes (De Wever et al., 2000), a phylogenetic study of $16 \mathrm{~S}$ rRNA genes from the 12 available Geobacter species that had been described at that time showed that the type strain of $T$. thiogenes fell within the Geobacter clade of the family Geobacteraceae (Snoeyenbos-West et al., 2001). The response of De Wever et al. to this study stated that, at the time of publication of the description of $T$. thiogenes, only two Geobacter species, Geobacter metallireducens $\left(\right.$ ATCC $53774^{\mathrm{T}}=$ DSM $7210^{\mathrm{T}}$ ) and Geobacter sulfurreducens (ATCC $51573^{\mathrm{T}}=$ DSM $12127^{\mathrm{T}}$ ), had validly published names and that phylogenetic analysis of additional genes ( $g y r B)$ was necessary (De Wever et al., 2001a). Subsequently, the names of other Geobacter species, Geobacter bremensis $\left(\right.$ ATCC BAA $-607^{\mathrm{T}}=$ DSM $12179^{\mathrm{T}}=\mathrm{Dfr} 1^{\mathrm{T}}=\mathrm{OCM} 796^{\mathrm{T}}$ ), Geobacter pelophilus (ATCC BAA- $603^{\mathrm{T}}=$ DSM $12255^{\mathrm{T}}=$ $\mathrm{Dfr}^{\mathrm{T}}=$ OCM $\left.797^{\mathrm{T}}\right) \quad($ Straub \& Buchholz-Cleven, 2001), Geobacter chapellei (DSM $13688^{\mathrm{T}}$ ), Geobacter grbiciae (ATCC BAA-45 $5^{\mathrm{T}}$ ), Geobacter hydrogenophilus (ATCC $\left.51590^{\mathrm{T}}=\mathrm{DSM} 13691^{\mathrm{T}}\right)($ Coates et al., 2001), Geobacter psychrophilus (JCM 12644 ${ }^{\mathrm{T}}$ ) and Geobacter bemidjiensis
(ATCC BAA-1014 ${ }^{\mathrm{T}}$ ) (Nevin et al., 2005), have been validly published. Furthermore, a phylogenetic study of the nifD, recA, gyrB, rpoB, fusA and 16S rRNA genes from 30 members of the Geobacteraceae has been conducted and the sequences deposited in GenBank/EMBL/DDBJ. The nucleotide and amino acid sequences of the following genes have been compared: $r p o B$, encoding the $\beta$-subunit of RNA polymerase; recA, encoding the DNA repair protein, RecA; gyrB, the structural gene for the DNA gyrase $\beta$-subunit; fusA, encoding the protein synthesis elongation factor, elongation factor-G; nifD, encoding the $\alpha$-subunit of the dinitrogenase protein; and the $16 \mathrm{~S}$ rRNA gene. The results demonstrate that the Geobacteraceae is a phylogenetically and physiologically distinct family within the Deltaproteobacteria and that $T$. thiogenes is clearly a member of the Geobacter clade of this family (Holmes et al., 2004).

Cytochrome analysis was performed on $T$. thiogenes, $G$. chapellei and G. sulfurreducens using cells grown in media described in the original descriptions with fumarate as electron acceptor and acetate as electron donor (Lovley et al., 2004). Three millilitres of culture was resuspended in $20 \mathrm{mM}$ PIPES ( $\mathrm{pH} \mathrm{7}$ ) and spectra were obtained as described previously (Caccavo et al., 1994) using a Shimadzu UV2401-PC dual beam spectrophotometer. The dithionite-reduced minus air-oxidized difference spectrum of $T$. thiogenes and G. chapellei showed the presence of $c$-type cytochromes, with absorbance peaks at 420 and $552 \mathrm{~nm}$ and a shoulder at $522 \mathrm{~nm}$. A similar spectrum was obtained from the control, G. sulfurreducens, with peaks and a shoulder at the same absorbance values. The presence of $c$-type 
cytochromes is a distinguishing feature of the family Geobacteraceae, with the exception of members of the genus Pelobacter. The cells of $T$. thiogenes are visibly pink, as are the cells of all Geobacter species.

T. thiogenes has not been reported previously to be able to reduce $\mathrm{Fe}(\mathrm{III})$. $\mathrm{Fe}(\mathrm{III})$ reduction is considered to be a hallmark trait of species of the genus Geobacter. Therefore, the $\mathrm{Fe}(\mathrm{III})$ reduction capability of $T$. thiogenes was evaluated. Cells of $T$. thiogenes were transferred four times in basal media (De Wever et al., 2000) containing $5 \mathrm{mM}$ $\mathrm{Fe}(\mathrm{III})$ nitriloacetate, $5 \mathrm{mM}$ acetate and $0.01 \mathrm{~g}$ yeast extract $1^{-1}$, in the presence and absence of hydrogen. Medium from the fifth transfer was monitored for $\mathrm{Fe}(\mathrm{II})$ using the ferrozine method (Lovley \& Phillips, 1986) to evaluate $\mathrm{Fe}(\mathrm{III})$ reduction, and direct cell counts (Lovley \& Phillips, 1988) were carried out to determine cell growth. T. thiogenes conserved energy for growth from the oxidation of acetate coupled to the reduction of Fe(III) (Fig. 1). The addition of hydrogen slightly increased the amount of $\mathrm{Fe}(\mathrm{III})$ reduced, but had no effect on cell number. The reduction of $\mathrm{Fe}(\mathrm{III})$ is a distinguishing characteristic of the family Geobacteraceae. All Geobacter species are capable of $\mathrm{Fe}$ (III) reduction, with acetate serving as the electron donor (Lovley et al., 2004).

T. thiogenes was tested for its ability to use a variety of electron donors and acceptors that its closest relative, G. chapellei, was capable of utilizing. A comparison between the electron donor and acceptor profiles of these two organisms is given in Table 1, together with DNA-DNA hybridization values, DNA $\mathrm{G}+\mathrm{C}$ content, temperature optimum and range and cytochrome content.

The temperature and $\mathrm{pH}$ range and optima for growth of $T$. thiogenes were determined. Tubes containing medium with fumarate as electron acceptor and acetate as electron donor, in triplicate, were used to determine growth at 4, 10, 17, 22,

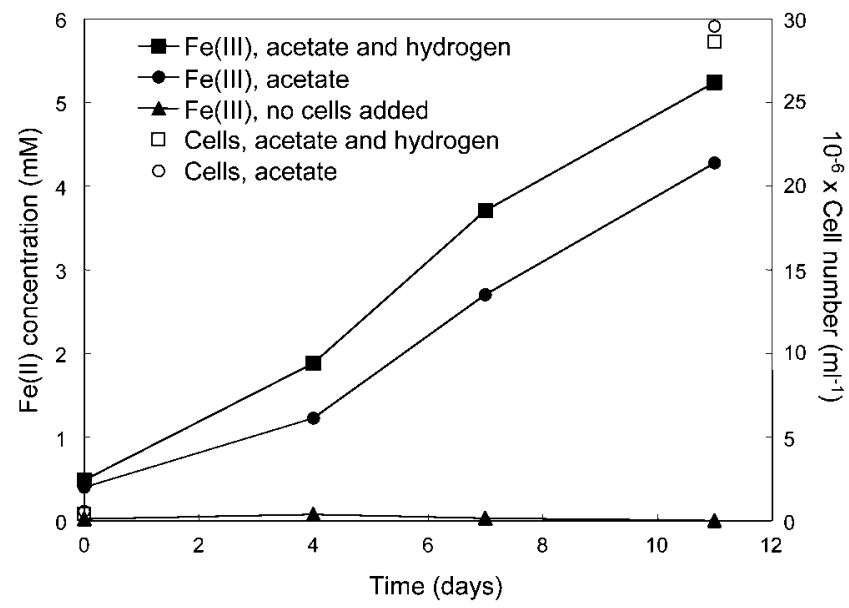

Fig. 1. Growth of cells of $G$. thiogenes strain $K 1^{\top}$ in basal medium with $\mathrm{Fe}$ (III) nitriloacetate as electron acceptor and acetate or acetate plus hydrogen as electron donor.
30,37 and $42{ }^{\circ} \mathrm{C}$. Growth was evaluated using $\mathrm{OD}_{600}$ values and microscopic examination. Growth occurred at 10, 17, 22, 30 and $37^{\circ} \mathrm{C}$, with optimum growth at $30^{\circ} \mathrm{C}$, which is typical of many Geobacter species. A circum-neutral $\mathrm{pH}$ optimum for growth was observed in media containing fumarate as electron acceptor and acetate as electron donor using $\mathrm{OD}_{600}$ values and microscopic examination.

Previous studies have suggested that placement of $T$. thiogenes in the appropriate genus in the Geobacteraceae should be based on phylogenetic comparisons of genes other than the 16S rRNA gene alone (De Wever et al., 2000,

Table 1. Physiological characteristics of Geobacter thiogenes strain $\mathrm{K}^{\top}$ and Geobacter chapellei strain $172^{\top}$ including use of various electron donors with fumarate as electron acceptor and various electron acceptors with acetate as electron donor

Unless indicated otherwise data for strain $\mathrm{K}^{\mathrm{T}}$ were taken from Jurgen Wiegel and Frank Loffler, this study and De Wever et al. (2000). Data for strain $172^{\mathrm{T}}$ were taken from Coates et al. (2001) and this study. Acetate $(10 \mathrm{mM})$ and 2,6-anthraquinone disulfonate (AQDS; $5 \mathrm{mM}$ ) tested positive as electron donors for the two strains; benzoate $(2 \mathrm{mM})$, butyrate $(10 \mathrm{mM})$, malate $(10 \mathrm{mM})$, propionate $(10 \mathrm{mM})$, pyruvate $(10 \mathrm{mM})$ and succinate $(10 \mathrm{mM})$ tested negative as electron donors for the two strains. $\mathrm{Fe}$ (III) pyrophosphate $(10 \mathrm{mM}), \mathrm{Fe}(\mathrm{III})$ nitriloacetate $(5 \mathrm{mM})$ and fumarate $(10-40 \mathrm{mM})$ tested positive as electron acceptors for the two strains; $\mathrm{Fe}(\mathrm{III})$ citrate $(55 \mathrm{mM})$, sulfate $(10 \mathrm{mM})$ and thiosulfate $(10 \mathrm{mM})$ tested negative as electron acceptors for the two strains. The DNA-DNA hybridization value between strains $\mathrm{K}^{\mathrm{T}}$ and $172^{\mathrm{T}}$ is $13 \%$ (data from DSMZ) and both strains contain cytochromes. NT, Not tested.

\begin{tabular}{|c|c|c|}
\hline Characteristic & $\begin{array}{c}\text { Geobacter } \\
\text { thiogenes } \\
\text { strain } \mathrm{K}^{\mathrm{T}}\end{array}$ & $\begin{array}{c}\text { Geobacter } \\
\text { chapellei } \\
\text { strain } 172^{\mathrm{T}}\end{array}$ \\
\hline DNA G $+\mathrm{C}$ content $(\mathrm{mol} \%)$ & 55.1 & 50.2 \\
\hline Temperature optimum $\left({ }^{\circ} \mathrm{C}\right)$ & 30 & 25 \\
\hline Temperature range $\left({ }^{\circ} \mathrm{C}\right)$ & $10-37$ & NT \\
\hline \multicolumn{3}{|l|}{ Donors: } \\
\hline Acetoin $(10 \mathrm{mM})$ & + & - \\
\hline Ethanol $(10 \mathrm{mM})$ & - & + \\
\hline Formate $(10 \mathrm{mM})$ & - & + \\
\hline Hydrogen $(130 \mathrm{kPa})^{*}$ & + & - \\
\hline Lactate $(10 \mathrm{mM})$ & - & + \\
\hline \multicolumn{3}{|l|}{ Acceptors: } \\
\hline Elemental sulfur $\left(20 \mathrm{~g} \mathrm{l}^{-1}\right)$ & + & - \\
\hline Fe(III) oxide $(100 \mathrm{mM})$ & NT & + \\
\hline Nitrate $(5 \mathrm{mM})$ & + & - \\
\hline Malate $(10 \mathrm{mM})$ & + & - \\
\hline $\mathrm{Mn}(\mathrm{IV})$ oxide $\left(20 \mathrm{~g} \mathrm{l}^{-1}\right)$ & - & + \\
\hline Trichloroacetic acid (5 mM) & + & - \\
\hline
\end{tabular}

*Acetate $(0.1 \mathrm{mM})$ was provided as carbon source for growth on hydrogen. 
2001a). Therefore, additional phylogenetic analysis of members of the family Geobacteraceae was conducted using the following genes: $r p o B$, recA, gyrB, fusA, nifD and $16 \mathrm{~S}$ rRNA (Holmes et al., 2004). These additional taxonomic comparisons demonstrated that $T$. thiogenes consistently groups within the freshwater Geobacter clade of the Geobacteraceae (Holmes et al., 2004). Similarity matrices generated using the similarity matrix program (Maidak et al., 2001), available on the Ribosomal database Project II website, and LFASTA version 3.2 (Pearson, 1990) demonstrated that $T$. thiogenes is most similar to G. chapellei. The $16 \mathrm{~S}$ rRNA gene sequence similarity between $T$. thiogenes and G. chapellei was $93.9 \%$, and the nucleotide and amino acid sequence similarities for the fus $A, g y r B$, nifD, recA and $r p o B$ genes were $77.9-91.8 \%$.

Concatamers were assembled with 1323 nucleotides from the 16S rRNA gene, 883 nucleotides from gyrB, 412 nucleotides from recA, 590 nucleotides from fusA, 540 nucleotides from $r p o B$ and 440 nucleotides from nifD. The genes used to construct the concatamers were submitted separately to GenBank (Holmes et al., 2004). Once constructed, the concatamers were aligned using CLUSTAL_X (Thompson et al., 1997) and imported into the Genetic Computer Group (GCG) sequence editor (Wisconsin Package version 10) where alignments were checked and hypervariable regions were masked. Aligned sequences were then imported into PAUP 4.0b 4a (Swofford, 1998), where phylogenetic distances were inferred. Comparisons of these concatamated alignments clearly demonstrate that $T$. thiogenes falls within the phylogenetically coherent Geobacter cluster of the family Geobacteraceae (Fig. 2). Analysis of concatamated alignments indicated that, similar to previous gene comparisons (Holmes et al., 2004), T. thiogenes is most similar to G. chapellei ( $81.3 \%$ genetic sequence similarity).

Members of the family Geobacteraceae have been detected or isolated from a wide variety of aquatic sediments and subsurface sediments. The ability of $T$. thiogenes to grow via reductive dehalogenation was a novel characteristic for members of the Geobacter cluster of the Geobacteraceae, but the capacity for dehalogenation has been observed previously in members of the Desulfuromonas cluster of this family (Krumholz et al., 1996; Krumholz, 1997; Löffler et al., 2000 ) and thus this characteristic alone does not warrant a new genus designation. Furthermore, a recently isolated strain of Geobacter, 'Geobacter lovleyi' strain SZ, is also capable of dechlorination (Sung et al., 2006). The finding that, like all Geobacter species, T. thiogenes is capable of $\mathrm{Fe}(\mathrm{III})$ reduction and contains abundant $c$-type cytochromes and that, using six separate genes, its phylogenetic placement within the Geobacter clade of the Geobacteraceae is maintained, indicates that $T$. thiogenes should be reclassified as a species of Geobacter.

\section{Description of Geobacter thiogenes comb. nov.}

Geobacter thiogenes (thi.o'ge.nes. Gr. n. thion sulfur; Gr. v. gennao produce; N.L. part. adj. thiogenes producing sulfur).

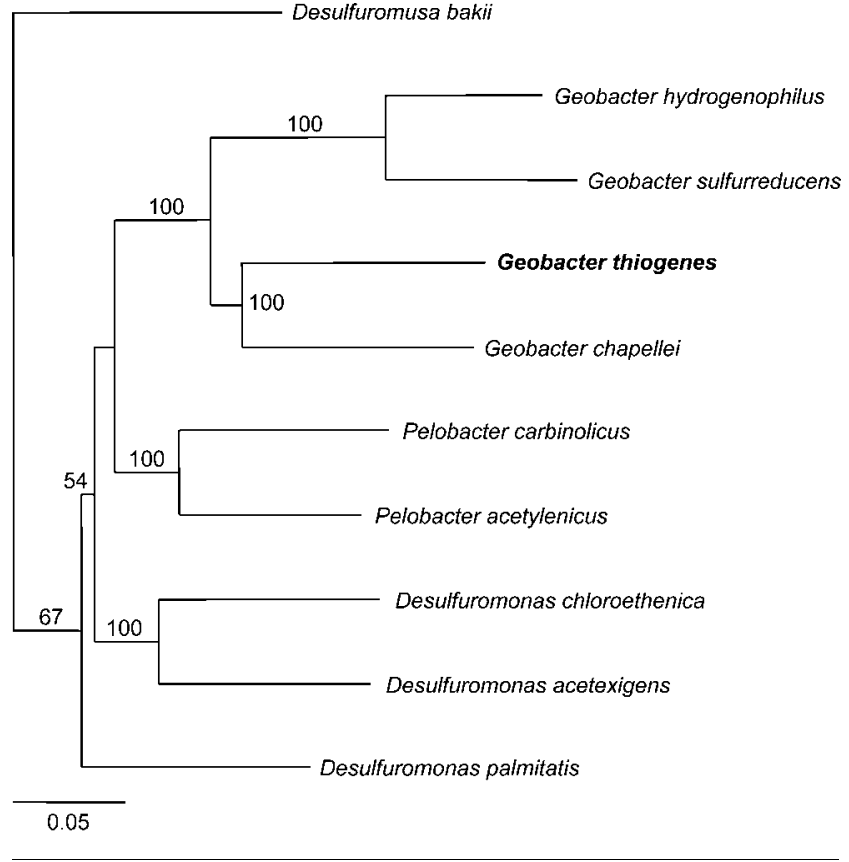

Fig. 2. Phylogenetic tree constructed with the HKY85 distance-based algorithm showing the relationship between concatamers assembled from $16 \mathrm{~S}$ rRNA, recA, nifD, rpoB, gyrB and fus $A$ gene fragments from the type strains of $G$. thiogenes and other species within the family Geobacteraceae. Desulfuromusa bakii was used as an outgroup. Bootstrap values were determined from 100 replicates. Bar, 0.05 nucleotide substitutions per site.

Basonym: Trichlorobacter thiogenes De Wever et al. 2001b.

Physiological data and phylogenetic analysis based on nifD, recA, gyrB, rpoB, fusA and 16S rRNA genes indicate that Trichlorobacter thiogenes is a member of the Geobacter clade of the family Geobacteraceae. Has the following properties in addition to those given in the original description. Capable of Fe(III) reduction. Cells contain abundant $c$-type cytochromes.

The type strain is $\mathrm{K}^{\mathrm{T}}\left(=\mathrm{ATCC}\right.$ BAA- $34^{\mathrm{T}}=\mathrm{JCM} 14045^{\mathrm{T}}$ ), which was enriched from subsoil from western Michigan with acetate as an electron donor and trichloroacetic acid as an electron acceptor.

\section{Acknowledgements}

This research was supported by the Office of Science (BER), US Department of Energy, Cooperative Agreement no. DE-FC0202ER63446 and Grant no. DE-FG02-97ER62475.

\section{References}

Caccavo, F., Jr, Lonergan, D. J., Lovley, D. R., Davis, M., Stolz, J. F. \& McInerney, M. J. (1994). Geobacter sulfurreducens sp. nov., a hydrogen- and acetate-oxidizing dissimilatory metal-reducing microorganism. Appl Environ Microbiol 60, 3752-3759. 
Coates, J. D., Bhupathiraju, V. K., Achenbach, L. A., McInerney, M. J. \& Lovley, D. R. (2001). Geobacter hydrogenophilus, Geobacter chapellei and Geobacter grbiciae, three new, strictly anaerobic, dissimilatory Fe(III)-reducers. Int J Syst Evol Microbiol 51, 581-588.

De Wever, H., Cole, J. R., Fettig, M. R., Hogan, D. A. \& Tiedje, J. M. (2000). Reductive dehalogenation of trichloroacetic acid by Trichlorobacter thiogenes gen. nov., sp. nov. Appl Environ Microbiol 66, 2297-2301.

De Wever, H., Cole, J. R., Fettig, M. R., Hogan, D. A. \& Tiedje, J. M. (2001a). Trichlorobacter thiogenes should be renamed as a Geobacter species: Author's reply. Appl Environ Microbiol 67, 1021-1022.

De Wever, H., Cole, J. R., Fettig, M. R., Hogan, D. A. \& Tiedje, J. M. (2001b). Trichlorobacter thiogenes gen. nov., sp. nov. In Validation of the Publication of New Names and New Combinations Previously Effectively Published Outside the IJSEM, List no. 78. Int J Syst Evol Microbiol 51, 1-2.

Holmes, D. E., Nevin, K. P. \& Lovley, D. R. (2004). Comparison of $16 \mathrm{~S}$ rRNA, nifD, recA, rpoB and fusA genes within the family Geobacteraceae fam. nov. Int J Syst Evol Microbiol 54, 1591-1599.

Krumholz, L. R. (1997). Desulfuromonas chloroethenica sp. nov. uses tetrachloroethylene and trichloroethylene as electron acceptors. Int J Syst Bacteriol 47, 1262-1263.

Krumholz, L. R., Sharp, R. \& Fishbain, S. S. (1996). A freshwater anaerobe coupling acetate oxidation to tetrachloroethylene dehalogenation. Appl Environ Microbiol 62, 4108-4113.

Löffler, F. E., Sun, Q., Li, J. \& Tiedje, J. M. (2000). 16S rRNA genebased detection of tetrachloroethene-dechlorinating Desulfuromonas and Dehalococcoides species. Appl Environ Microbiol 66, 1369-1374.

Lovley, D. R. \& Phillips, E. J. P. (1986). Availability of ferric iron for microbial reduction in bottom sediments of the freshwater tidal Potomac River. Appl Environ Microbiol 52, 751-757.

Lovley, D. R. \& Phillips, E. J. P. (1988). Novel mode of microbial energy metabolism: organic carbon oxidation coupled to dissimilatory reduction of iron or manganese. Appl Environ Microbiol 54, 1472-1480.

Lovley, D. R., Holmes, D. E. \& Nevin, K. P. (2004). Dissimilatory $\mathrm{Fe}(\mathrm{III})$ and $\mathrm{Mn}(\mathrm{IV})$ reduction. Adv Microb Physiol 49, 219-286.

Maidak, B. L., Cole, J. R., Lilburn, T. G., Parker, C. T., Saxman, P. R., Farris, R. J., Garrity, G. M., Olsen, G. J., Schmidt, T. M. \& Tiedje, J. M. (2001). The RDP-II (Ribosomal Database Project). Nucleic Acids Res 29, 173-174.

Nevin, K. P., Holmes, D. E., Woodard, T. L., Hinlein, E. S., Ostendorf, D. W. \& Lovley, D. R. (2005). Geobacter bemidjiensis sp. nov. and Geobacter psychrophilus sp. nov., two novel Fe(III)-reducing subsurface isolates. Int J Syst Evol Microbiol 55, 1667-1674.

Pearson, W. R. (1990). Rapid and sensitive sequence comparisons with FASTP and FASTA. Methods Enzymol 183, 63-98.

Snoeyenbos-West, O., Van Praagh, C. G. \& Lovley, D. R. (2001). Trichlorobacter thiogenes should be renamed as a Geobacter species. Appl Environ Microbiol 67, 1020-1022.

Straub, K. L. \& Buchholz-Cleven, B. E. E. (2001). Geobacter bremensis sp. nov. and Geobacter pelophilus sp. nov., two dissimilatory ferric-iron-reducing bacteria. Int J Syst Evol Microbiol 51, 1805-1808.

Sung, Y., Fletcher, K. E., Ritalahti, K. M., Apkarian, R. P., RamosHernández, N., Sanford, R. A., Mesbah, N. M. \& Löffler, F. E. (2006). Geobacter lovleyi sp. nov. strain SZ, a novel metal-reducing and tetrachloroethene-dechlorinating bacterium. Appl Environ Microbiol 72, 2775-2782.

Swofford, D. L. (1998). PAUP*: Phylogenetic Analysis Using Parsimony (*and other methods). Version 4. Sunderland, MA: Sinauer Associates.

Thompson, J. D., Gibson, T. J., Plewniak, F., Jeanmougin, F. \& Higgins, D. G. (1997). The CLUSTAL_X windows interface: flexible strategies for multiple sequence alignment aided by quality analysis tools. Nucleic Acids Res 25, 4876-4882. 